\title{
Como identidade engaja jovens negros de periferia? Uma análise empírica do movimento negro em Sorocaba-SP
}

\section{Matheus Henrique Hilário dos Santos Fagundes*, Luciana Ferreira Tatagiba}

\section{Resumo}

O seguinte projeto tem como tema a produção simbólica da identidade negra nos movimentos sociais de periferia urbana. Este projeto tem como objetivo entender as especificidades do que se entende enquanto "movimento negro" em relação ao conjunto dos movimentos sociais. Essa necessidade se dá, pois, utilizando como referência a teoria de movimentos sociais norte-americana e europeia, constata-se a ausência desse debate, e de mesmo modo, na literatura da Ciência Política em geral. Desse modo, através dessa pesquisa, o objetivo é apontar novas práticas da juventude negra e periférica na cidade de Sorocaba- SP que atestam essas mudanças de paradigmas e a necessidade de se incluir o debate racial nas áreas.

Palavras-chave: movimentos sociais, movimento negro, ação coletiva.

\section{Introdução}

A seguinte pesquisa inicialmente possuía o intuito de discutir os rolezinhos, fluxos e batidões de rua na cidade de Sorocaba (cidade do interior de São Paulo) a partir dos marcos teóricos do tema sobre o "direito à cidade"; das discussões acerca do racismo enquanto sistema estrutura; sobre o gênero musical funk, a cultura negra, periférica e os rolezinhos enquanto fenômenos político-culturais. A relação de como os rolezinhos em bairros nobres representavam disputas políticas e mobilizavam diversos dissensos e conflitos, em associação à criminalização das festas nas periferias, representou que havia algo de movimento social nessas práticas. Entretanto, conforme o trabalho de campo foi sendo realizado, novos personagens surgindo, gerando novas perguntas, sendo estas o objetivo de resposta deste trabalho: Como e a partir do que a juventude negra e periférica tem acesso ao debate racial? De que forma se organizam? Quais os sentidos de suas organizações? Com estas perguntas, afunilou-se à uma única: Como identidade engaja jovens negros de periferia? Os objetos não deixaram de ser os rolezinhos, fluxos e batidões de rua, porém se somaram aos coletivos culturais, coletivos político-partidários, organizações institucionais, clubes recreativos, movimento hip-hop, do funk e os salões de cabeleireiro.

\section{Resultados e Discussão}

Com o andamento do campo, chegou-se à hipótese de que o que caracteriza o movimento negro atualmente é justamente o trabalho em cima da relação cultura e política (Rios, 2010). Todos esses grupos e movimentos, a partir dos resultados da pesquisa, apontam para uma síntese: todos são parte do chamado "movimento negro", que se exibe enquanto especifico, fragmentado mas articulado, especialmente em redes que fazem parte das dinâmicas de vida da população negra. Donos dos salões, que frequentam o clube negro da cidade e realizam debates por lá, organizam coletivos negros ou de identidade periférica. Nos finais de semana participam dos fluxos em seus bairros para se divertir. A identidade coletiva dos atores presentes nesses diversos espaços é a negra, que se forma conforme os conflitos raciais diários individuais e coletivos ocorrem. Disso, os repertórios de suas organizações se mostram pautadas em repertórios de interações (Abers, Serafim, Tatagiba, 2014) por vezes de conflito ou de colaboração com o estado. O enquadramento interpretativo que o movimento cria é aquele que procura ligar a identidade coletiva negra junto à aspectos culturais contra as dinâmicas políticas que afetam esse grupo (Dagnino, 1994), como a violência policial, a desigualdade social, o genocídio, encarceramento, o desemprego, a baixa-autoestima e o racismo e o sexismo em geral. A metodologia empregada foi a de revisão bibliográfica sobre movimentos sociais e movimento negro; etnografias nas festas, batalhas e eventos. E por fim, entrevistas semiestruturadas com ativistas, cabeleireiros e membros das organizações.

\section{Conclusões}

Conclui-se que a formação de uma identidade enquanto ser negro contribui no engajamento, especialmente desse jovens. $O$ contato com pessoas negras, sejam elas referências políticas, familiares ou o cabeleireiro e o contato com manifestações culturais de origem negra (o funk, samba, o hip-hop) são os locais de acesso ao debate racial e auxiliam na formação dessa identidade. Estes espaços não são tradicionalmente entendidos enquanto movimentos sociais, mas a pesquisa apontou que são, pois fazem política articulando-a à raça e cultura, em ligação à uma rede de movimento(s) negro(s), procurando engajar para dar resposta à dinâmicas políticas que afetam esse grupo, como as de desigualdade e violência.

\section{Agradecimentos}

Agradecimentos ao $\mathrm{CNPq}$ pelo auxílio. À Luciana, pela oportunidade e apoio e à Rodger Richer pelas ótimas conversas e contribuições.

MCADAM, Doug; TARROW, Sidney; TILLY, Charles. Para mapear o confronto político. Lua Nova, São Paulo, n. 76, p. 11-48, 2009.

ALONSO, Angela. As teorias dos movimentos sociais: um balanço do debate. Lua Nova, São Paulo, n. 76, p. 49-86, 2009.

RIOS, Flávia Movimento negro brasileiro nas Ciências Sociais (1950-2000) Sociedade e Cultura, v. 12, n. 2, p. 263-274, 2010.

DAGNINO, Evelina. Os movimentos sociais e a emergência de uma nova cidadania. Anos 90 - Política e sociedade no Brasil. Ed. Brasiliense, São Paulo, pág. 103-115, 1994.

ABERS, Rebecca; SERAFIM, Lizandra; TATAGIBA, Luciana. Repertórios de interação estado-sociedade em um estado heterogêneo: a experiência na Era Lula. Dados, Rio de Janeiro, v. 57, n. 2, p. 325-357, 2014. 